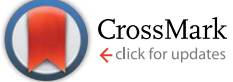

Cite this: RSC Adv., 2015, 5, 57950

Received 29th January 2015

Accepted 17th June 2015

DOI: $10.1039 / c 5 r a 01810 b$

www.rsc.org/advances

\section{Calf thymus DNA characterization and its adsorption on different silica surfaces}

\author{
Senem Yetgin* and Devrim Balkose
}

DNA adsorption is the initial stage of gene therapy for drug delivery systems and solid phase extraction methods of DNA purification. High pore volume and high adsorption capacity are simple requirements not only for producing 'smart' drug delivery systems but also the development of purification kits. Silica is the most used material for this purpose. The present study aimed at elucidating the calf thymus DNA biosorption process by the characterization of calf thymus DNA and silica to increase the efficiency of the currently used silica material. Mesoporous silica has long been used for DNA adsorption and silica aerogel is the new adsorbent investigated in the present study. When DNA solution was freeze dried on a silica wafer, self-assembled super helices formed as shown by atomic microscopy (AFM). Thus DNA existed not as single molecules but as large sized agglomerates in water. Thus it could be adsorbed in the macropores and on the external surface of adsorbents. Adsorption of calf thymus DNA to a silica aerogel, a mesoporous silica gel and a silica wafer was investigated in the present study. Silica aerogel was synthesized from TEOS by a supercritical ethanol drying process. The DNA adsorption capacity of the silica aerogel was nearly two times that of the mesoporous silica gel due to its macroporous structure and its higher silanol content. Silica aerogel was found to be a very promising material for DNA adsorption. Therefore silica aerogel can be considered as a good candidate for the delivery of DNA.

\section{Introduction}

Nano and micro particles have many functions such as antibacterial, ${ }^{1}$ detection in chemical analysis, ${ }^{2}$ tumor cell targeting, ${ }^{3}$ polymer composites, ${ }^{4,5}$ stable semiconductor material ${ }^{6}$ and DNA delivery systems. ${ }^{7}$ Recent studies have been focused on development of DNA related nanomaterials and nanotechnologies and the creation of nano-sized structures. Consequently DNA is used for gene therapy, biological sensor preparation, tumor targeting delivery host for targeted drugs, gene and functional nanoscale electronic device, programmable DNAdirected self-assembly film and DNA-conjugated metal nanoparticles. ${ }^{8-15}$ Besides DNA chips and DNA microarrays are used in molecular biology, pharmaceutical industry and clinical research to identify presence of specific biological targets. ${ }^{\mathbf{1 6}}$

These kinds of technologies require pure DNA usage and understanding of DNA interaction with surfaces. Not only DNA purification but also DNA interactions with different surfaces are directly or indirectly based on the adsorption of DNA. In the case of DNA purification Solid Phase Extraction (SPE) is the most useful and harmless technique for DNA purification. Silica is the most commonly used material for SPE and increasing its adsorption capacity is firstly required.

Department of Chemical Engineering, Izmir Institute of Technology, 35430 Gulbahce Urla,Izmir, Turkey.E-mail: devrimbalkose@iyte.edu.tr; senemyetgin@gmail.com
An inorganic material, typically in the form of amorphous mesoporous silica $\left(\mathrm{SiO}_{2}\right)$ is one of the preferred matrices for delivery host. On the other hand silica aerogel has been in attention recently because of its tuneable physical properties of pore size, surface area (e.g.).

Nucleic acids are adsorbed on silica and glass surfaces under chaotropic solution conditions because of negatively charged structure of DNA. Its adsorption by silica was extensively investigated. ${ }^{17-19}$ It is reported that silanol group through the surface enhance the interaction.

Generally both mechanism of DNA adsorption by silica and adsorption capacity are the investigated points. DNA adsorption was controlled by the three effects (i) weak electrostatic repulsion forces, (ii) dehydration, and (iii) hydrogen bond formation. Also the presence of a monovalent cation such as $\mathrm{Na}^{+}$neutralizes the negative charges on the phosphate backbone of DNA, reducing the electrostatic barrier between DNA and silica. ${ }^{1}$ Therefore DNA adsorption capacity is increased. Silica particles in microchips ${ }^{16}$ and miniaturized set up $^{20}$ were used successfully for solid phase extraction of DNA. There are controversial approaches to the aggregation state of DNA adsorbed on porous solids. DNA fibres having 30-40 $\mathrm{nm}$ diameter were observed between the edges and surfaces of particles when Bacillus subtilis DNA was adsorbed on clay. They were not adsorbed as single molecules but as fibres consisting of many molecules. ${ }^{21}$ However $\beta$-type duplex DNA molecules bearing a straight cylindrical structure with a diameter of $2 \mathrm{~nm}$ were included in 
the pore void of M41S type mesoporous silicas having linear cylindrical spaces with diameters in the range from 2 to $5 \mathrm{~nm} .^{22}$ siRNA research was carried out with silica having 3-4 nm diameter pores and 440-450 $\mathrm{nm}$ narrow particle size distribution. Because of its high pore volume silica met the requirement of loading small interfering RNA. ${ }^{23}$

Possibility of inclusion of DNA and siRNA into mesopores of mesoporous silica was investigated by Fujiwara et $a .^{22}$ and Mayen et al. ${ }^{23}$ respectively. Mesoporous silicas with 2.80 or 3.82 $\mathrm{nm}$ peak pore diameters adsorbed DNA the best in diluted $\mathrm{NaCl}$ solution. Formation of the hydrogen bond between $\mathrm{P}(\mathrm{O}) \mathrm{OH}$ groups in DNA and adsorbed water, $\mathrm{SiOH}$ groups, or both on silica surfaces was regarded as a main factor in this adsorption. The coincidence of the pore sizes and DNA diameter realizes this unique adsorption promoted by the effect of encompassing DNA with the inner surface of mesoporous silica.

Fortunately sol gel chemistry allows adjusting the pore size of derived materials. The pore dimensions of silica can be obtained in suitable size for loading large molecules. Sol-gel derived amorphous silica $\left(\mathrm{SiO}_{2}\right)$ is known to be biocompatible. This type of silica was also confirmed as suitable for delivery of drugs, nucleic acids (DNA, siRNA) and proteins. ${ }^{24}$

Silica aerogel is a special material that has high surface area and porosity. ${ }^{25}$ Therefore it is also well known nanomaterial with low density, low dielectric constant and isolation properties. It has been used in different scientific research due to its high surface area, open pore structure and biocompatibility since its discovery in 1931. ${ }^{26,27}$ Space engineering, ${ }^{28}$ energy collectors, ${ }^{29,30}$ thermal insulation in solar window systems ${ }^{31}$ and catalytic supports $^{32,33}$ are some of the usage areas of silica aerogel. Recently silica aerogel has been used increasingly in biomedical application because of its release properties of enzymes and drugs. ${ }^{34}$ Drugs, enzymes and proteins are added to silica aerogel during the preparation or the drying procedure. ${ }^{35-38}$ Not only drug release but also medical application of aerogel has gained attention recently. For example Sabri and coworkers tested long terms of histological evaluation on different intramuscular and subcutaneous aerogel implants on organs. ${ }^{39}$ Polyurea crosslinked monolithic silica aerogel implants have been found promising for spleen, lung, heart, kidney, and intestine. Without any infection and mild level fibrosis with inflammation silica aerogel has been defined as biocompatible. Its biocompatible property has been also proved for tissue engineering scaffold application of poly- $\varepsilon$-caprolactone composite. ${ }^{40}$ Aerogel minimize the acidic condition after polymer decomposition. Therefore 3T3 and primary mouse osteoblastic cells were long term stabilized around pH level of 7.2 and 7.4. Biochip for molecular recognition of nucleotide acids is another application of aerogel on biomedical application. ${ }^{\mathbf{4 1}}$ The aerogel having high surface area was found to be capable of identifying human gene ATP5O.

Aerogel having mesopores was produced under regular atmospheric conditions using the sol-gel process. ${ }^{42}$ Silica aerogel has the advantage of manipulating its physical properties during preparation. ${ }^{\mathbf{4 3}}$ These preparation procedures have included three general reversible reactions: hydrolysisesterification, alcohol condensation-alcoholysis, and water condensation-hydrolysis. Alcogels were formed in the sol-gel process. Therefore the factors that affect the reaction steps change quality and properties of alcogel and indirectly aerogel. Aerogels can be obtained by addition of soluble organic matter during preparation to enlarge the pore diameter ${ }^{\mathbf{4 2}}$ or by supercritical fluid drying techniques. In supercritical ethanol drying the pores of the alcogel were not collapsed since there were no interfacial tension between the pore walls and gaseous ethanol.

Calf thymus DNA can be used in studying DNA-silica interactions. It is a highly polymerized water soluble polymer with molecular weight higher than $6 \times 10^{6} \mathrm{~g} \mathrm{~mol}^{-1} \cdot{ }^{\mathbf{4 4 , 4 5}}$

In the present study characterization of calf thymus DNA in size and charge and its adsorption on mesoporous silica gel and silica aerogel were aimed to elucidate the DNA biosorption. Silica aerogel with a high pore volume and surface area was prepared for adsorption of calf thymus DNA. Supercritical ethanol drying technique was used to obtain the aerogel powder. Both DNA and aerogel were well characterized by advanced analytical techniques before adsorption experiments. Adsorption of DNA from aqueous solutions to the silica aerogel and a mesoporous silica gel was investigated by Nano Drop method, and morphology of freeze dried DNA on silica wafer was investigated by AFM.

\section{Experimental}

\section{Materials}

Tetraethoxysilane (98\%, Aldrich), ethanol (99.8\% Riedel, ammonia) (28-30\%, Aldrich) were used in preparing silica alcogel. Mesoporous silica gel from Sigma-Aldrich-Silicagel (Grade 7734 pore size $6 \mathrm{~nm}$, particle size 70-230 mesh) was also used for DNA adsorption experiments. Sodium salt of calf thymus DNA supplied by Sigma-Aldrich (D1501) was used in adsorption experiments.

\section{Methods}

Preparation of silica alcogel. Silica alcogel was prepared by a two steps sol gel procedure. The details of the method developed by Brinker and co-workers have been described by $\mathrm{Ru}$ and coworkers. ${ }^{46}$ Hydrochloric acid was used as an acid catalyst of the hydrolysis of tetraethylorthosilicate (TEOS) in the first step. TEOS, ethanol (EtOH), distilled water and hydrochloric acid were mixed in a $250 \mathrm{~cm}^{3}$ glass bottle at a molar ratio of $1: 6: 4: 10^{-3}$ and led to be stirred for $30 \mathrm{~min}$, and a hydrolysis solution was obtained. In the second step, ammonia, as a base catalyst, was added drop-wise into the solution resulting from the first step, at the molar ratio of TEOS : $\mathrm{NH}_{4} \mathrm{OH}$ equals to $1: 10^{-2}$. The alcogel formed by keeping the mixture for 940 hours at $25{ }^{\circ} \mathrm{C}$ was washed several times with ethanol. The aim of this part is to remove excess water present inside the alcogel structure. After preparation of the silica alcogel and the washing procedure, the alcogel having $84.3 \%$ ethanol, $1.1 \%$ water and $14.6 \%$ silica was dried by ethanol supercritical drying.

Supercritical ethanol drying of silica alcogel. The super critical ethanol drying set up shown in Fig. 1 was used in drying the silica alcogel. The system has a temperature controlled 300 
$\mathrm{cm}^{3}$ PARR 4561 reactor and a $300 \mathrm{~cm}^{3}$ PARR expansion vessel. Both reactors have a net volume of $272 \mathrm{~cm}^{3}$. In a typical experiment, approximately $5.0 \mathrm{~g}$ of silica alcogel and $100 \mathrm{~cm}^{3}$ ethanol was placed in the reactor. First nitrogen gas was passed from the system by opening valves $1,2,3$ and 4 to remove oxygen from the system. Then all the valves were closed and the reactor was heated to bring ethanol to a supercritical state. Since the critical temperature and pressure of ethanol are $241{ }^{\circ} \mathrm{C}$ and 6.36 $\mathrm{MPa}$ by heating to $250^{\circ} \mathrm{C}$ and 7.2 MPa pressure a supercritical state was achieved. The ethanol and silica alcogel mixture was stirred at $600 \mathrm{rpm}$ during heating for heat transfer from external heater and for obtaining aerogel particles. The valve 2 between the reactor and expansion vessel was opened at $250{ }^{\circ} \mathrm{C}$ temperature. The gauge pressure in the system was decreased to zero in this process as shown in the phase diagram of ethanol in Fig. 2. The ethanol in supercritical state is expanded into expansion vessel at room temperature and condensed there as a liquid. Heating is stopped and the system was opened when it was cooled to room temperature. The silica aerogel particles were collected from the reactor and the ethanol in liquid phase was taken from expansion vessel.

Characterization of commercial silica and silica aerogel. Tapped bulk densities of commercial silica gel and silica aerogel were determined by measuring their masses packed in a

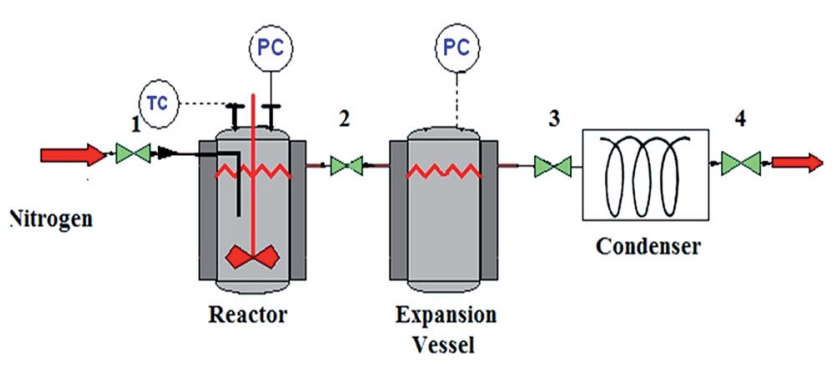

Fig. 1 Flow sheet of supercritical ethanol drying system.

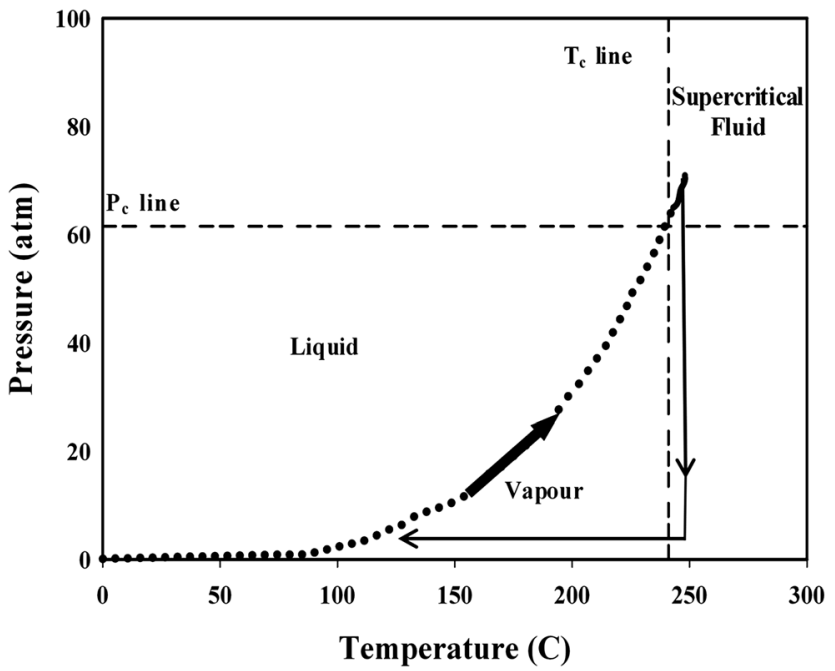

Fig. 2 Pressure-temperature relation of ethanol in closed reactor and the operating line for supercritical ethanol drying. known volume container. The surface properties of the prepared aerogel and the commercial silicagel were determined through nitrogen adsorption at $77 \mathrm{~K}$ using Micromeritics ASAP 2000.

Commercial silicagel, aerogel and DNA morphologies were determined by SEM (FEI Qanta 250 FEG instruments). FTIR spectra of the samples were taken with Shimadzu 8601 FTIR spectrophotometer by $\mathrm{KBr}$ disc method to obtain functional group information in the bulk of the samples. The change of surface functional groups with temperature was examined by in situ drift FTIR spectroscopy. Diffuse Reflectance Fourier Transform Infrared (DRIFT) measurements were carried out in an in situ heating reaction cell fitted with $\mathrm{CaF}_{2}$ windows (Harricks, NY) shown in Fig. 3. A praying mantis optical geometry was used to direct the infrared beam. A $0.1 \mathrm{~g}$ DNA sample was placed on the sample holder and after its spectrum at room temperature and $100 \mathrm{KPa}$ pressure was taken, the sample chamber was evacuated down to the $0.1 \mathrm{~Pa}$ pressure and heated up to $500{ }^{\circ} \mathrm{C}$ at a $2{ }^{\circ} \mathrm{C} \mathrm{min}^{-1}$ rate at the same pressure. The DRIFT spectra of the sample were obtained at different temperatures during its dynamic heating.

Characterization of DNA. The surface charge and the particle size distribution of dissolved DNA in water at different $\mathrm{pH}$ values were determined by using Malvern Zetasizer 2000. For this purpose $100 \mathrm{ng} \mathrm{mm}^{-3}$ DNA in $0.001 \mathrm{~mol} \mathrm{dm}^{-3}$ buffer solutions were prepared. For $\mathrm{pH} 2$ glycin- $\mathrm{HCl}, \mathrm{pH} 3$ and 4 potassium hydrogen phthalate- $\mathrm{HCl}, \mathrm{pH} 5$ and 6 acetate, $\mathrm{pH}$ 7, 8 and 10 phosphate buffers were used. The refractive index of DNA was considered to be 1.5. This value is general for polymeric material and measurements done at $0.001 \mathrm{M}$ ionic strength. ${ }^{47}$

The adsorption of DNA from aqueous solutions at pH 5 on silica aerogel and commercial silica gel were investigated. Before the analysis $100 \mathrm{ng} \mathrm{mm}^{-3}$ calf thymus DNA solution was softly shaken to obtain a homogeneous DNA sample stock solution at $\mathrm{pH} 5$ in acetate buffer solution (ionic strength is $0.001 \mathrm{M})$. Solutions having $10-90 \mathrm{ng} \mathrm{mm}^{-3}$ DNA were prepared by diluting the stock solution with the buffer solution.

Adsorption experiments. The adsorption isotherms of calf thymus DNA from aqueous solutions were determined by

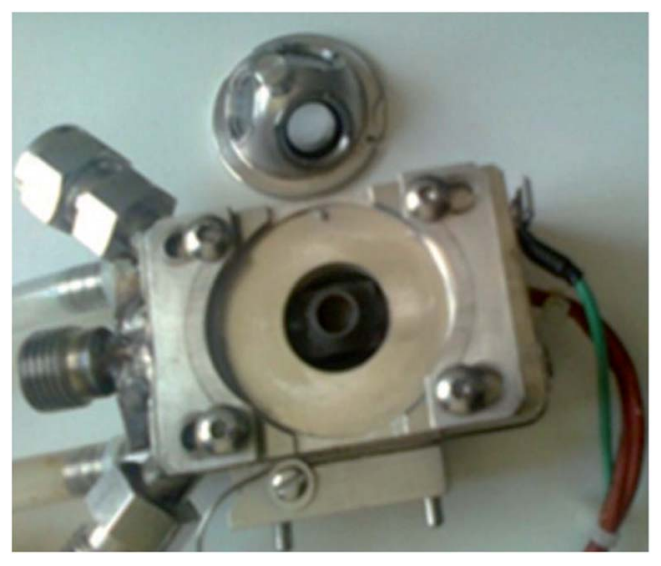

Fig. 3 Harricks in situ reaction cell with $\mathrm{CaF}_{2}$ windows. 
measuring the DNA concentrations in solutions in equilibrium with mesoporous silica gel and silica aerogel synthesized in the present study. Before the adsorption experiment all adsorbents were dried at $120{ }^{\circ} \mathrm{C}$ for 18 hours under vacuum. The DNA concentration was measured at $260 \mathrm{~nm}$. The DNA concentration was measured at $260 \mathrm{~nm}$. The A260/A280 ratios of calf thymus DNA solutions were 1.8 indicating no protein or RNA contamination. Subsequently $0.0075 \mathrm{mg}$ of adsorbent $\left(\mathrm{SiO}_{2}\right)$ was added to the $1.5 \mathrm{~cm}^{3}$ DNA solution to get a solid to liquid ratio $5 \mathrm{~g}$ $\mathrm{dm}^{-3}$. DNA concentration of the supernatant was measured by using Nano Drop Thermo Scientific ND-1000 UV-VIS spectrophotometer after mixing at 100-200 rpm by Fine PCR mixer incubator at $25{ }^{\circ} \mathrm{C}$ for 24 hours.

Morphology of DNA adsorbed on silica wafer. Adsorbed DNA on silica surfaces was examined by atomic force microscopy. Calf thymus DNA was dissolved in ultrapure water $(\mathrm{pH} 7-0.055$ $\mu \mathrm{S} \mathrm{cm}^{-1}$ ) to a concentration of $100 \mu \mathrm{g} \mathrm{cm}^{-3}$ at $\mathrm{pH} 5.2 \mu \mathrm{l}$ of 100 $\mu \mathrm{g} \mathrm{cm}{ }^{-3}$ of calf thymus DNA was placed onto the surface of a silica wafer polished in $c$ plane (0001) (CS analytic company) by using a micropipette. DNA solution droplet on the surface was dried by freeze drying method. The silica wafer having DNA solution drop were placed in vials containing $1 \mathrm{~cm}^{3}$ frozen water. The vial was placed in freeze drying equipment (Labconco Free Zone-4.5) and the drying was carried out at $-51{ }^{\circ} \mathrm{C}$ under vacuum till all the frozen water was evaporated. Thus DNA particles in solution were dried on the surface of the silica wafer without any change in their conformation.

The AFM, Digital Instruments MMSPM Nanoscope IV was used in the tapping mode to obtain the 2 and 3-dimensional surface topology, and phase information of the surfaces in air. For imaging in air, Veeco RTESP tips were used. The tips had anisotropic geometry, with tip height $15-20 \mu \mathrm{m}$ and tip radius less $10 \mathrm{~nm}$. The spring constant of the cantilever was $40 \mathrm{~N} \mathrm{~m}^{-1}$. Nominal length and width of the cantilever were 125 and $35 \mu \mathrm{m}$ respectively. The typical tapping frequency was $263-291 \mathrm{kHz}$, the scanning rate was $1.0 \mathrm{~Hz}$ and scan angle was zero degrees.

\section{Results and discussion}

\section{DNA characterization}

Morphology of dry calf thymus DNA. Images of calf thymus DNA as received are shown in Fig. 4. Calf thymus DNA sample has a very complex structure. It was in form of fibres having 2 to $5 \mu \mathrm{m}$ diameters. These fibres were consisted of super helices from 1000-2500 molecules.

Zeta potential of DNA. Some special studies have been focused on the DNA isoelectric point and DNA stability in ionic solution. ${ }^{48}$ The isoelectric point of DNA from different sources is reported about to be $\mathrm{pH} 5.0 .^{\mathbf{4 9}, 50}$ Fig. 5 displays zeta potential distributions of DNA at $\mathrm{pH}$ values of 2.2, 4, 5 and 7. Zeta potential was determined by the mobility of ions in an electric field and the mobility depends on the particle size and particle charge. DNA particles are not identical to each other, they both size and charge distribution due to their intermolecular interactions. Thus a distribution in zeta potential was also observed. The zeta potentials of calf thymus DNA was reported to have a distribution by previous reported investigations. ${ }^{51}$ The average

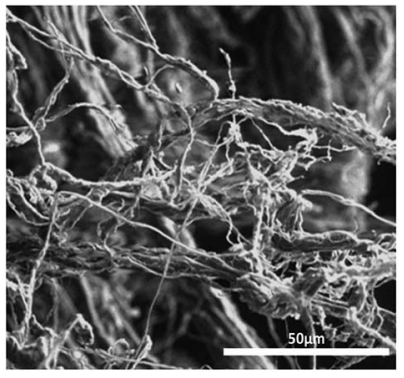

(a)

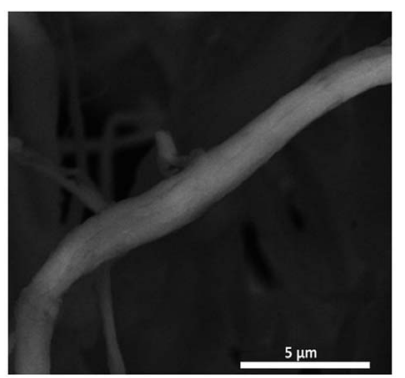

(b)
Fig. 4 SEM images of calf thymus DNA at (a) $1000 \times$ (b) $2000 \times$ magnification.

zeta potentials were calculated from the distributions shown in Fig. 5. The change of average zeta potential of DNA with $\mathrm{pH}$ is shown in Fig. 6. Zeta potential measurements in the present study showed that calf thymus DNA solutions had isoelectric point near the pH 2 value.

DNA particle size in aqueous solution. Size characterization of the DNA was made by dynamic light-scattering (DLS) measurements using the Zetasizer.

Considering the information of $0.34 \mathrm{~nm}$ helix rise per turn, 10.5 base pair per helical turn for the double helix of B-DNA ${ }^{52}$ and the average molar mass of a base pair as $650 \mathrm{~g} \mathrm{~mol}^{-1}$, the length of calf thymus DNA molecules should be 300 and $400 \mathrm{~nm}$ for $6 \times 10^{6}$ and $8 \times 10^{6} \mathrm{~g} \mathrm{~mol}^{-1}$ molar $^{-1}$ mass of DNA reported in ref. 44 and 45 . If the self-assembled fibres in dry form were dispersed into their individual molecules, particles having $2 \mathrm{~nm}$ diameter and 4.18 and $3.18 \mu \mathrm{m}$ length should be present in aqueous solutions. Since there is a lower limit of sizes that can be determined by the Zetasizer, the particle size distribution shown in Fig. 7 should give information about the length of the fibres not about their diameter. DNA in solution had the particle size distribution shown in Fig. 7. The particle size ranged from 300 to $800 \mathrm{~nm}$ and it was $490 \mathrm{~nm}$ on the average as seen in Fig. 7. The breadth of the distribution curve at half height was $230 \mathrm{~nm}$.

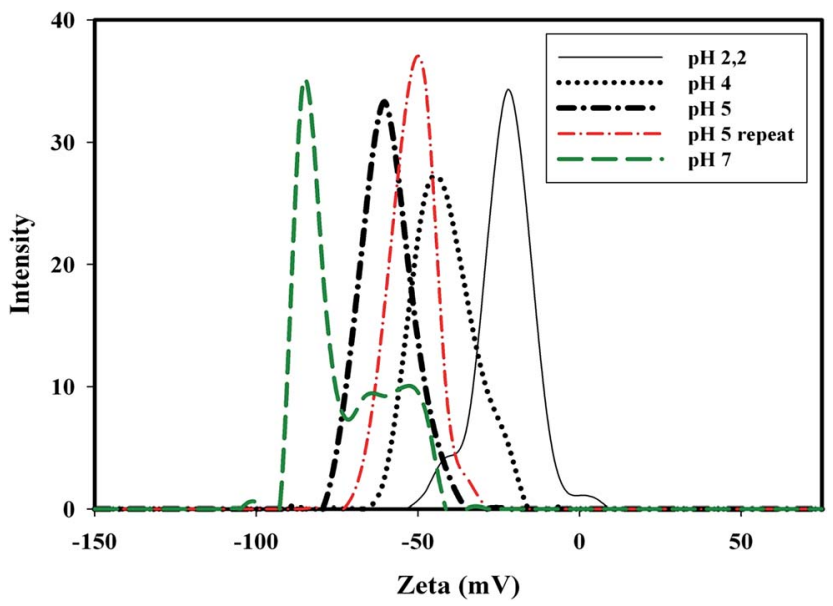

Fig. 5 Zeta potential distribution of calf thymus DNA at different $\mathrm{pH}$ values. 


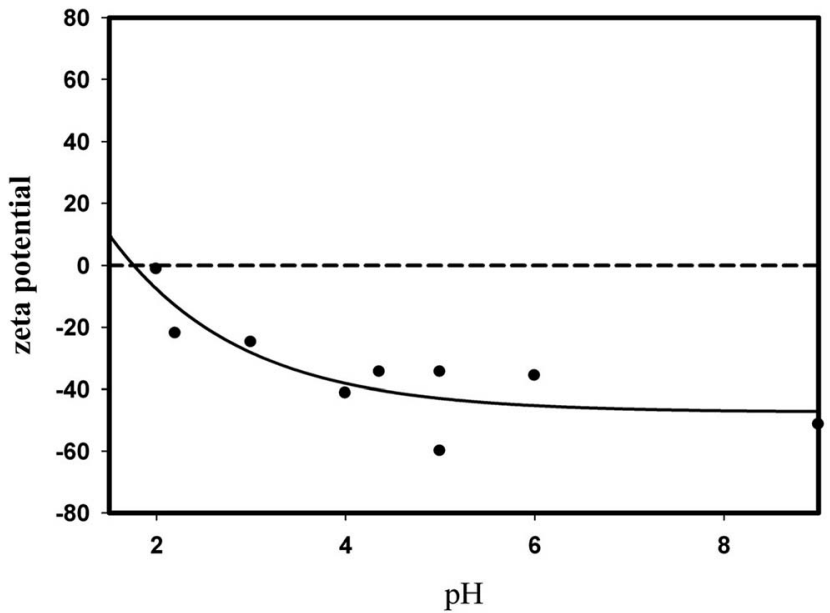

Fig. 6 Change of the average zeta potential of calf thymus DNA with all $\mathrm{pH}$ values.

\section{Silica characterization}

Morphologies of mesoporous silica gel and silica aerogel. Morphologies of mesoporous silica gel and silica aerogel are observed in Fig. 8. There are large flat surfaces in silica aerogel since it was not contracted during drying process. The average size of the particles of mesoporous silica gel was found to be 162 $\pm 90 \mu \mathrm{m}$ from SEM micrographs. The aerogel also had a particulate structure since it was continuously stirred during aerogel preparation. The average particle size of the aerogel was around $163 \pm 92 \mu \mathrm{m}$. The average particle sizes were determined by counting 100 particles from several SEM micrographs.

Surface characterization by nitrogen gas adsorption. The nitrogen adsorption isotherms of the aerogel and mesoporous silica gel are as shown in Fig. 9. The aerogel had $1107 \mathrm{~m}^{2} \mathrm{~g}^{-1}$ surface area and $4.2 \mathrm{~nm}$ pore diameter as determined by nitrogen gas adsorption at $77 \mathrm{~K}$. Data for aerogel and the commercial silica gel were as listed in Table 1. The mesopore size distributions of aerogel and commercial silica gel (Fig. 10) were determined from the desorption branch of the nitrogen adsorption isotherms using Kelvin equation, eqn (1).

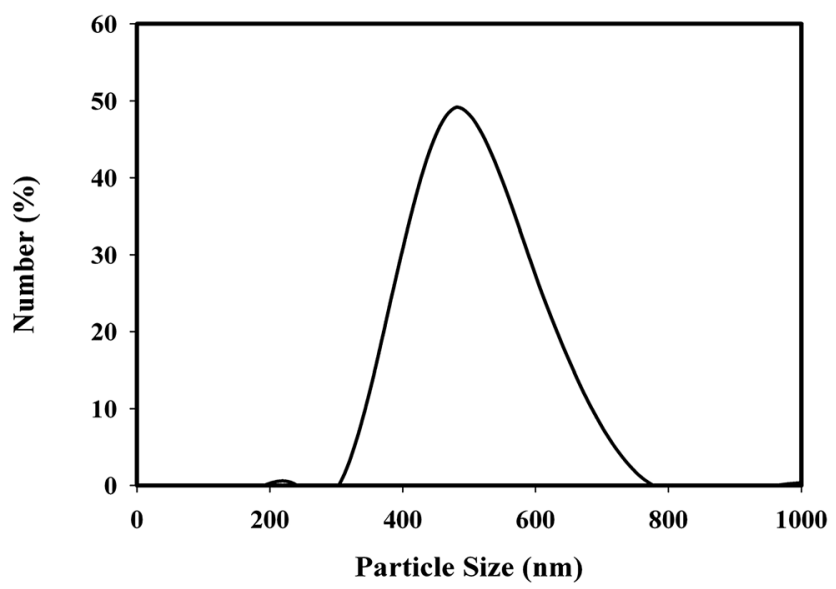

Fig. 7 Number particle size distribution of DNA dissolved in water.

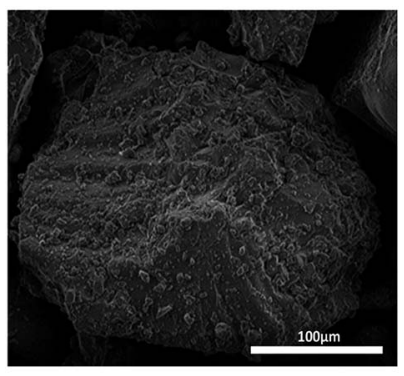

(a)

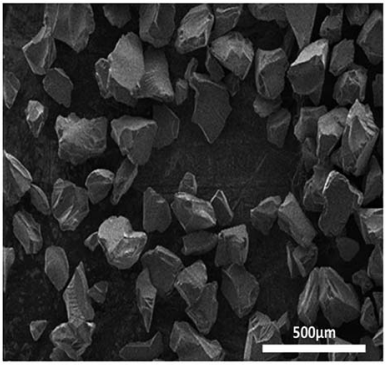

(c)

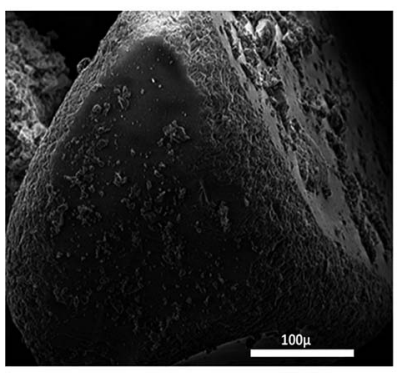

(b)

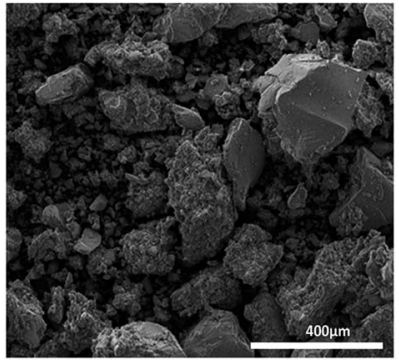

(d)
Fig. 8 Morphology of (a) commercial silica gel at $1000 \times$ (b) silica aerogel at $788 \times$ (c) commercial silica gel at $65 \times$ magnification (d) silica aerogel at $250 \times$ magnification.

$$
\ln \left(P / P_{0}\right)=2 \gamma V_{\mathrm{m}} / r R T
$$

where $P$ is the actual vapour pressure, $P_{0}$ is the saturated vapour pressure, is the surface tension of liquid nitrogen, $V_{\mathrm{m}}$ is the molar volume of liquid nitrogen, $R$ is the universal gas constant, $r$ is the radius of the pore, and $T$ is temperature. Surface tension and molar volumes of liquid nitrogen are $8.8 \mathrm{mN} \mathrm{m}^{-1}$ and 34.7 $\mathrm{cm}^{3} \mathrm{~mol}^{-1}$ respectively at $77 \mathrm{~K}$. The mesopore volume of silica aerogel is much higher than silica gel as seen in Fig. 10.

Only micropore and mesopore volumes can be determined by $\mathrm{N}_{2}$ adsorption. Thus the total pore volume should be determined using other methods. The tapped bulk densities of the mesoporous silica gel and silica aerogel were determined as

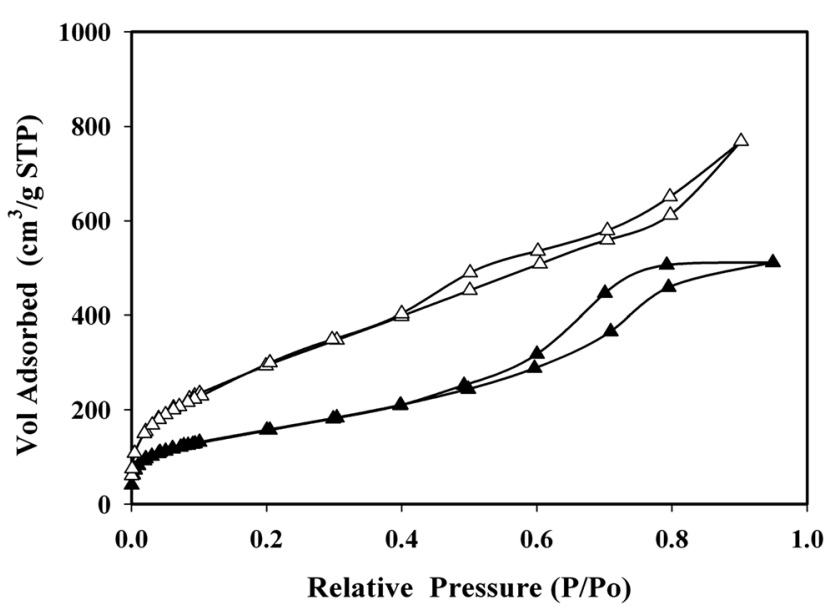

Fig. 9 Nitrogen adsorption and desorption isotherms of Aerogel $(\Delta)$ and commercial silica gel ( $\mathbf{\Lambda}$ ). 
Table 1 Surface characteristics of the aerogel and mesoporous silica gel

\begin{tabular}{|c|c|c|}
\hline Properties & Silica gel & Aerogel \\
\hline Single point surface area $\left(\mathrm{m}^{2} \mathrm{~g}^{-1}\right)$ & 556 & 1055 \\
\hline BET surface area $\left(\mathrm{m}^{2} \mathrm{~g}^{-1}\right)$ & 571 & 1107 \\
\hline Langmuir surface area $\left(\mathrm{m}^{2} \mathrm{~g}^{-1}\right)$ & 787 & 1549 \\
\hline Average pore diameter (nm) (4V/A by BET) & 5.5 & 4.2 \\
\hline $\begin{array}{l}\text { Total pore volume }\left(\mathrm{cm}^{3} \mathrm{~g}^{-1} \text { ) }\right. \\
\text { (single point from } \mathrm{N}_{2} \text { adsorption) }\end{array}$ & 0.79 & 1.19 \\
\hline (From tapped bulk density measurements) & 0.74 & 7.00 \\
\hline Max micropore volume $\left(\mathrm{cm}^{3} \mathrm{~g}^{-1}\right)$ & 0.20 & 0.36 \\
\hline Mesopore volume $\left(\mathrm{cm}^{3} \mathrm{~g}^{-1}\right)$ & 0.59 & 0.73 \\
\hline
\end{tabular}

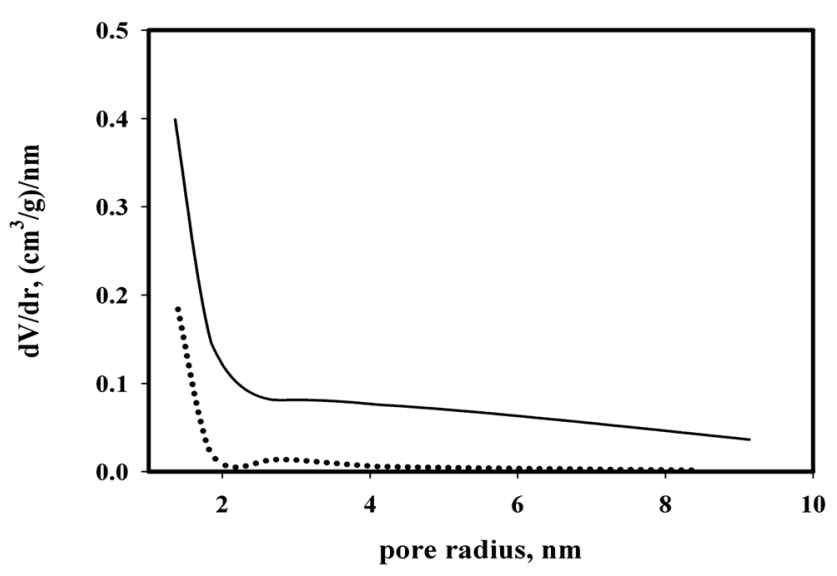

Fig. 10 Pore size distribution of silica aerogel (-) and commercial silica gel (...).

$0.56 \mathrm{~g} \mathrm{~cm}^{-3}$ and $0.09 \mathrm{~g} \mathrm{~cm}^{-3}$ respectively. Considering random packing particles void volume fraction as 0.33 and density of silica as $2.2 \mathrm{~g} \mathrm{~cm}^{-3}$ the total pore volumes were calculated as 0.73 and $7 \mathrm{~cm}^{3} \mathrm{~g}^{-1}$ respectively for mesoporous silica gel and silica aerogel respectively. While the total pore volumes determined by nitrogen adsorption and from bulk density measurements were close to each other for mesoporous silica gel, they were different from each other for silica aerogel. The silica aerogel had pore volume of 7 and $1.19 \mathrm{~cm}^{3} \mathrm{~g}^{-1}$ from bulk density measurement and from $\mathrm{N}_{2}$ adsorption respectively. Thus there were macropores in silica aerogel which would allow the entrance of large DNA particles.

Functional groups of silica aerogel and silica gel. As can be seen in the FTIR spectra in Fig. 11 and 12 the prepared silica aerogel and the mesoporous silica gel had characteristic peaks of silica. The peak at $3400 \mathrm{~cm}^{-1}$ is related to the hydrogen bonded $\nu \mathrm{O}-\mathrm{H}$ mode of residual silanol $(\mathrm{Si}-\mathrm{OH})$ groups and of adsorbed water. ${ }^{53}$ Another silanol band, assigned to the $\mathrm{Si}-\mathrm{OH}$ bending mode become visible at $950 \mathrm{~cm}^{-1}$. The strongest band, with maximum absorption at $\sim 1100 \mathrm{~cm}^{-1}$, is assigned to the asymmetric $\mathrm{Si}-\mathrm{O}-\mathrm{Si}$ stretching mode.

Mesoporous silica had lower concentration of silanol ( $\mathrm{Si}-$ $\mathrm{OH})$ groups since the ratio of the absorbance values at 950 $\mathrm{cm}^{-1} / 1100 \mathrm{~cm}^{-1}$ are 0.13 and 0.15 respectively for mesoporous silica gel and aerogel respectively. Silica aerogel adsorbed more

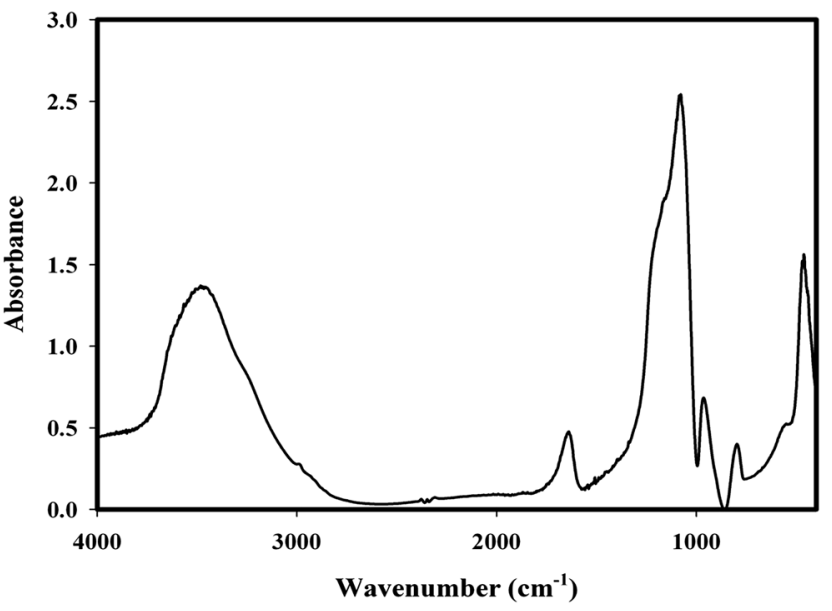

Fig. 11 FTIR spectrum of silica aerogel.

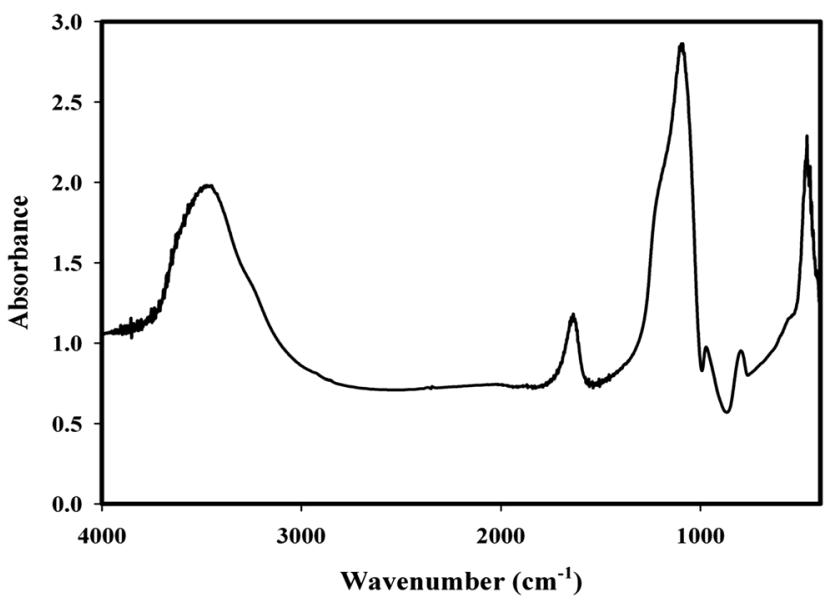

Fig. 12 FTIR spectrum of commercial silica gel.

DNA than mesoporous silica gel; since DNA was bonded to silica surface through silanol groups ${ }^{21}$ silica aerogel was macroporous and had higher surface area.

In situ drying behaviour of conventional and supercritical ethanol dried silica. DRIFT FTIR spectroscopy gives information about the surface of the particles. The DRIFT spectrum of silica aerogel at $25{ }^{\circ} \mathrm{C}$ at $0.1 \mathrm{~Pa}$ pressure in Fig. 13 showed hydrogen bonded $\mathrm{OH}$ groups peak at $3400 \mathrm{~cm}^{-1}, \mathrm{H}_{2} \mathrm{O}$ bending peak at $1600 \mathrm{~cm}^{-1}$ and multiple peaks related to $\mathrm{Si}-\mathrm{O}-\mathrm{Si}$ stretching vibrations being maximum at $1100 \mathrm{~cm}^{-1}$. When silica aerogel was heated to high temperatures, water and hydrogen bonded $\mathrm{OH}$ groups are eliminated from its structure as seen by the decrease of the intensity of $3400 \mathrm{~cm}^{-1}$ band. A new peak appears on heated aerogel at $3742 \mathrm{~cm}^{-1}$ belonging to isolated $\mathrm{Si}-\mathrm{OH}$ groups. ${ }^{54}$ The absorbance of this peak increased up to heating to $100{ }^{\circ} \mathrm{C}$ and then remained constant up to heating to $500{ }^{\circ} \mathrm{C}$ indicating the presence of $\mathrm{Si}-\mathrm{OH}$ groups at the surface of the aerogel (Fig. 14).

Adsorption isotherm of DNA on aerogel and silica gel. DNA adsorption isotherms are illustrated in Fig. 15. 22.52\% and $8.41 \%$ uptakes from $100 \mathrm{ng} \mu^{-1}$ DNA solution at $\mathrm{pH} 5$ were 


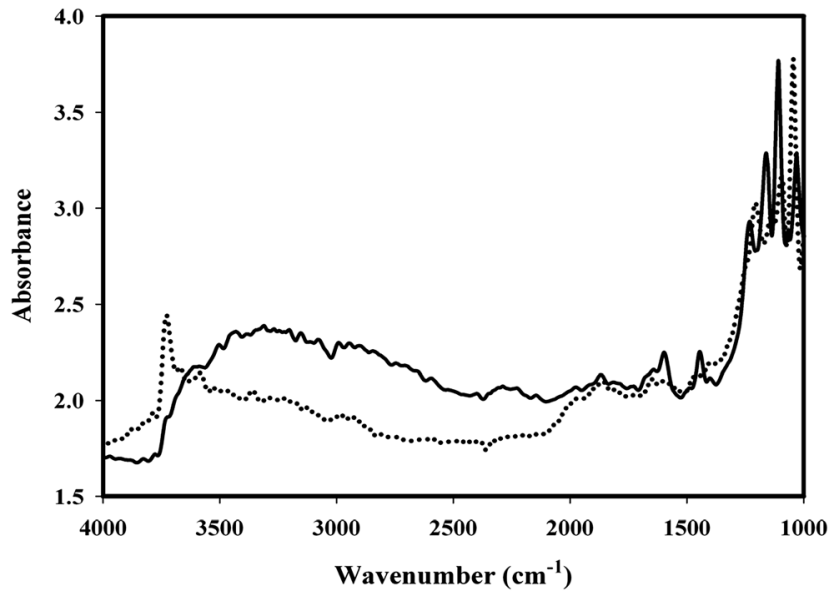

Fig. 13 FTIR DRIFT spectra of aerogel at $0.1 \mathrm{~Pa}$ and $25^{\circ} \mathrm{C}(-)$ and at $500{ }^{\circ} \mathrm{C}(\ldots)$.

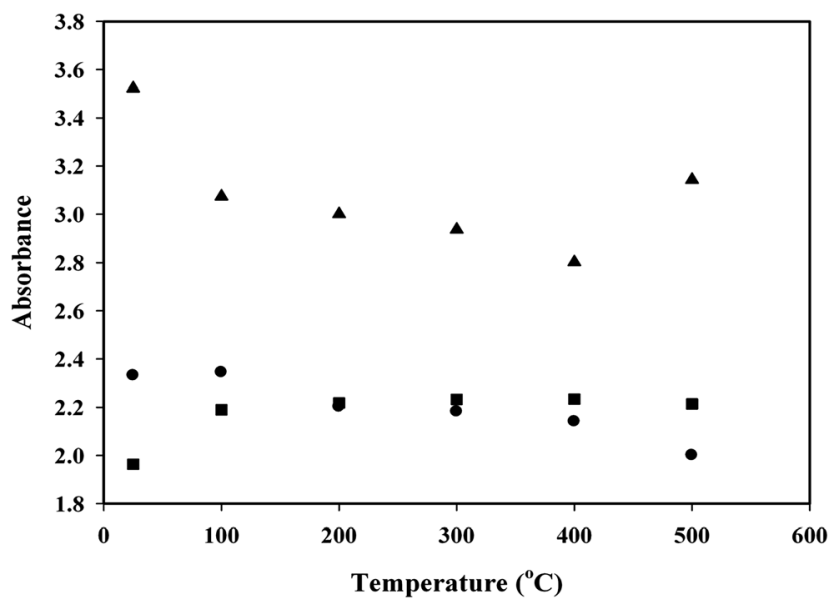

Fig. 14 Absorbance values at $3700 \mathrm{~cm}^{-1}(\boldsymbol{\square}), 1100 \mathrm{~cm}^{-1}(\boldsymbol{\Delta})$ and $3400 \mathrm{~cm}^{-1}(\mathbf{0})$ versus temperature for silica aerogel.

determined for silica aerogel and commercial silica gel respectively. It was found that the DNA adsorption capacity was higher for silica aerogel than that of commercial silica gel. This could be due to higher concentration of $\mathrm{Si}-\mathrm{OH}$ groups and higher total pore volume of silica aerogel.

The adsorption of self-assembled DNA on silica aerogel and silica gel should be a complicated process. Langmuir and Freunlich adsorption models developed for adsorption of small molecules on solid surfaces were applied to DNA adsorption as an over simplification. The Langmuir model shown in eqn (2) assumes monolayer adsorption onto homogeneous surfaces, whereas the semiempirical Freundlich model in eqn (3) works well for heterogeneous surfaces at low concentrations that do not show a finite uptake capacity.

$$
1 / Q_{\mathrm{e}}=1 / Q_{\mathrm{m}}+1 / b Q_{\mathrm{m}} C_{\mathrm{e}}
$$

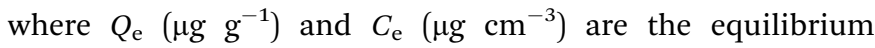
concentrations in solid and solution phase respectively. The Langmuir coefficients $b$ and $Q_{\mathrm{m}}$ are related to the energy of adsorption and the maximum adsorption capacity respectively.

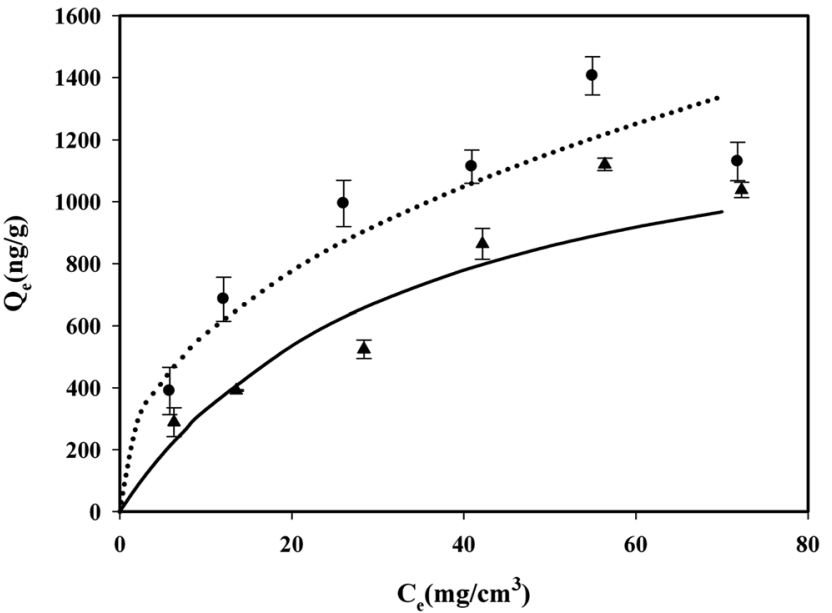

Fig. 15 Adsorption isotherm of DNA on silica aerogel and silica gel at $\mathrm{pH} 5$ aerogel experimental (O), silicagel experimental $(\boldsymbol{\Delta})$, aerogel model (Freunlich) (...), silica gel model (Langmuir) (-).

$$
\log Q_{\mathrm{e}}=\log K_{\mathrm{f}}+1 / n \log C_{\mathrm{e}}
$$

$K_{\mathrm{f}}$ and $n$ are equilibrium constants (temperature dependent) related to adsorption capacity and intensity, respectively.

Langmuir and Freundlich model graphs were drawn for silica aerogel and mesoporous silica gel. Both isotherm models fit to adsorption data with $R^{2}$ values higher than 0.8. $R^{2}$ values were higher for Langmuir and Freundlich models for mesoporous silica gel and silica aerogel respectively. However $R^{2}$ value was higher, (0.96) for Freundlich model for silica aerogel, and it was higher (0.90) for Langmuir model for silica gel as reported in Table 2.

The Langmuir adsorption capacities of DNA with 7000 base pairs to silica with $3.4,5.4,10.0 \mathrm{~nm}$ pore sizes and treated with $\mathrm{Mg}^{2+}$ ions were $2.49,5.71$ and $15.7 \mu \mathrm{g} \mathrm{mg}^{-1}$ respectively. Silica with $5.4 \mathrm{~nm}$ pore size and treated with $\mathrm{Na}^{+}$ions had a smaller adsorption capacity, only $0.22 \mu \mathrm{g} \mathrm{mg}^{-3}$. On the other hand salmon sperm DNA was adsorbed in the $0.5-2.7 \mu \mathrm{g} \mathrm{mg}^{-1}$ range on mesoporous silica with different pore sizes at $\mathrm{pH}$ value of 7.43 in $0.005 \mathrm{~mol} \mathrm{dm}^{-3} \mathrm{NaCl}$ solution. ${ }^{6}$ The aerogel synthesized in the present study had $2.5 \mu \mathrm{g} \mathrm{mg}^{-1}$ adsorption capacity at $\mathrm{pH}$ 7 for highly polymerized DNA.

DNA images on silica wafer by atomic force microscopy (AFM). Freeze dried DNA particles adsorbed on a flat silica surface were imaged by atomic force microscopy to observe their agglomeration state in water. The DNA on silica surface was obtained by drying a droplet of a DNA solution by freeze drying. The AFM image of dry DNA particles on silica surface shows the original state of molecules present in aqueous solution since interfacial attractions between solid water and DNA are negligible during freeze drying. The phase AFM image of DNA on silica surface is seen in Fig. 16. The DNA molecules in super helix form and in particulate form are present as seen in the figure. The average end to end distance of the super helices was $2.85 \pm 0.74 \mu \mathrm{m}$ and their average diameter was $0.10 \pm 0.1$ $\mu \mathrm{m}$. The average pitch of the helices was $0.15 \mu \mathrm{m}$. The particles in spherical form had also a distribution and their average size 
Table 2 Langmuir and Freundlich isotherm model constants

\begin{tabular}{lllllllll}
\hline & \multicolumn{3}{c}{ Langmuir Model } & & & \multicolumn{2}{l}{ Freundlich model } \\
\cline { 2 - 3 } & $\begin{array}{llllllll}Q_{\mathrm{m}} \\
\left(\mu \mathrm{g} \mathrm{g}^{-1}\right)\end{array}$ & $\begin{array}{l}b \\
\left(\mathrm{~cm}^{3} \mu \mathrm{g}^{-1}\right)\end{array}$ & $R^{2}$ & & & $\begin{array}{l}K_{\mathrm{f}} \\
\left(\mu \mathrm{g}^{1-n} \mathrm{~g}^{-1} \mathrm{~cm}^{-3 n}\right)\end{array}$ & $R^{2}$ \\
\hline Silica gel & 1428 & 0.031 & 0.90 & 1.67 & 94 & 0.83 \\
Aerogel & 2500 & 0.037 & 0.84 & 2.30 & 211 & 0.96
\end{tabular}

was $0.1 \mu \mathrm{m}$. The dimensions of the super helices indicate how many DNA molecules may involve in their formation. Considering the $2 \mathrm{~nm}$ diameter of a double helix of DNA, super helices were formed from nearly 500 DNA double helices. Thus the DNA present as single molecules could not be observed in the AFM image shown in Fig. 16. Even if they were existed, they would not be seen, since they were in a smaller scale than the lower detection limit of the AFM operating mode used in the present study. While the average particle size of DNA particles were determined as $490 \mathrm{~nm}$ by Zetasizer, the AFM image of the adsorbed DNA on the silica wafer showed that they were not present as single molecules, but as super helices in water.

\section{Discussion}

Adsorption is a process that should be taken in consideration of both the adsorbate and the adsorbent. Therefore characterization of the adsorbate calf thymus and mesoporous silica and synthesised aerogel adsorbents are important. DNA dispersion in water is important in determining the size of the pores in the adsorbent which they can enter. Thus the size of the DNA agglomerates both by Zetasizer and AFM. Freeze drying on silica wafer allowed us to determine the both morphology of the DNA on flat silica surface and its original dimensions in water. Zeta potential of DNA and silica at the adsorption $\mathrm{pH}$ were both negative, thus the adsorption was due to van der waals attraction and hydrogen bonding of DNA with Si-OH groups. Thus synthesizing aerogel with macropores and higher silanol content allowed adsorption of large agglomerates of DNA in silica.

DNA dissolved in water was not present as single molecules in the present study on contrary to the observations of Fujiwara et al. ${ }^{22}$ DNA dissolved in water had $490 \mathrm{~nm}$ average size as determined by Zetasizer. AFM studies indicated the presence of self-assembled super helices with $2.85 \pm 0.74 \mu \mathrm{m}$ length and with $0.10 \pm 0.1 \mu \mathrm{m}$ average diameter and $0.15 \mu \mathrm{m}$ pitch. Since highly polymerized calf thymus DNA in the aqueous phase was present as self-assembled large particles they could only be adsorbed in macropores and on the external surface of the silica particles rather than its micro and mesopores. Bacillus subtilis DNA was also adsorbed in fibre form on another adsorbent, clay $^{21}$ similar to calf thymus DNA on silica wafer.

Silica aerogel had smaller pore diameter $(4.2 \mathrm{~nm})$ than that of silica gel $(5.5 \mathrm{~nm})$ in micro and mesopore region. On the other hand the surface area of silica aerogel $\left(1107 \mathrm{~m}^{2} \mathrm{~g}^{-1}\right)$ was higher than that of mesoporous silica gel $\left(571 \mathrm{~m}^{2} \mathrm{~g}^{-1}\right)$. If the size ( $490 \mathrm{~nm}$ by Zetasizer, $2.85 \mu \mathrm{m}$ in length, $100 \mathrm{~nm}$ in diameter by AFM) of the DNA particles dispersed in water is considered, the entrance of DNA in the micro and meso pores was not possible. Thus the higher adsorption capacity of aerogel could be explained by the presence of macropores and the higher concentration of $\mathrm{Si}-\mathrm{OH}$ groups in aerogel.

After successful initial stage adsorption, the next stage is investigation of desorption. DNA was desorbed from mesoporous silica with magnetic particles by using an elution buffer with $150 \mathrm{mM} \mathrm{NaCl}$ and by increasing temperature to $37^{\circ} \mathrm{C} . .^{55}$

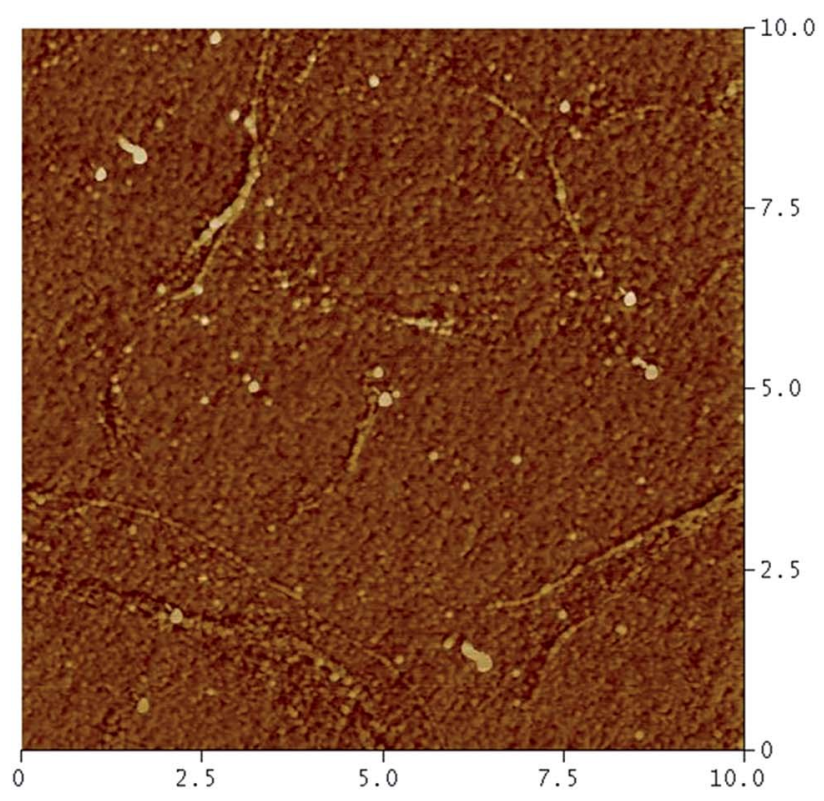

$\mu \mathrm{m}$

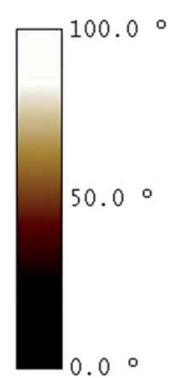

$\begin{array}{lc}\text { Digital Instruments } & \text { Nanoscope } \\ \text { Scan size } & 10.00 \mu \mathrm{m} \\ \text { Scan rate } & 1.001 \mathrm{~Hz} \\ \text { Number of samples } & 512 \\ \text { Image Data } & \text { Phase } \\ \text { Data scale } & 100.0^{\circ}\end{array}$

Fig. 16 Phase AFM image of DNA on silica wafer. 
DNA made hydrogen bonds with silanol groups on adsorption and the hydrogen bonds were broken during desorption ${ }^{55}$ DNA was adsorbed both in the external surface and in the mesopores. DNA in mesopores required a higher temperature than DNA on external surface to desorption to eluting buffer indicating stronger hydrogen bond formation in mesopores than the external surface. ${ }^{55}$

\section{Conclusions}

A silica aerogel was obtained by supercritical ethanol drying technique in the present study. It had a higher surface area and total pore volume than a mesoporous silica gel obtained by conventional drying. The adsorption of highly polymerized calf thymus self-assembled DNA in the aqueous phase should occur on the macropores and the external surface of the silica particles rather than its pores. Silica aerogel had nearly two times the adsorption capacity than the mesoporous silica gel. DNA adsorption onto silica surface is related with silanol group and silanol group is directly proportional with surface area. In situ drift FTIR spectroscopy indicated the presence of isolated $\mathrm{OH}$ groups in silica aerogel. The higher content of silanol groups and presence of macropores had positive effects on DNA adsorption capacity in silica aerogel. While DNA adsorption in silica aerogel best fitted to Freundlich isotherm with $K_{\mathrm{f}}$ and $n$ constants of 211 and 2.3 respectively, it fitted to Langmuir model with $Q_{\mathrm{m}} 1428 \mathrm{ng} \mathrm{\textrm {mg } ^ { - 1 }}$ and $b 0.031 \mathrm{~cm}^{3} \mu \mathrm{g}^{-1}$ for mesoporous silica gel. Adsorption sites in silica aerogel had a distribution of energies (Freundlich isotherm), while in mesoporous silica gel equal energy adsorption sites (Langmuir) were present.

DNA adsorption is the initial stage of gene therapy for drug delivery and DNA purification system. High pore volume and high adsorption capacity are the simple requirements of producing 'smart' drug delivery system and kit. Consequently silica aerogel was found to be a very promising material for DNA adsorption. Silica aerogel therefore presents an excellent material for a short-term DNA delivery system provided it can be made to release DNA in a safe and efficacious manner into living vasculature and/or tissues.

\section{Notes and references}

1 C. Dong, Z. Yan, J. Kokx, D. B. Chrisey and C. Z. Dinu, Appl. Surf. Sci., 2012, 258, 9218-9222.

2 Q. Xu, P. Pu, J. Zhao, C. Dong, C. Gao, Y. Chen, J. Chen, Y. Liua and H. Zhoua, J. Mater. Chem. A, 2015, 3, 542-546.

3 Z. Yu, R. M. Schmaltz, T. C. Bozeman, R. Paul, M. J. Rishel, K. S. Tsosie and S. M. Hecht, J. Am. Chem. Soc., 2013, 135, 2883-2886.

4 E. Sahin, F. Y. Mahlicli, S. Yetgin and D. Balkose, J. Appl. Polym. Sci., 2012, 125, 1448-1455.

5 S. Yetgin, S. Ulutan and D. Balkose, J. Vinyl Addit. Technol., 2015, 21(1), 42-50.

6 T. O. Egbuchunam, S. Yetgin, F. O. Omurlu and D. Balkose, Int. J. Appl. Eng. Res., 2014, 9(21), 11631-11646.
7 D. D. Dunlap, A. Maggi, M. R. Soria and L. Monaco, Nucleic Acids Res., 1997, 25(15), 3095-3101.

8 C. A. Mirkin, R. L. Letsinger, R. C. Mucic and J. J. Stofhoff, Nature, 1996, 382, 607-609.

9 E. Winfree, F. Liu, L. A. Wenzler and N. C. Seeman, Nature, 1998, 394, 539-544.

10 E. Braun, Y. Eichen, U. Sivan and G. Ben-Joseph, Nature, 1998, 391, 775-778.

11 H. W. Fink and C. Schonenberger, Nature, 1999, 398, 407410.

12 Z. Yu, R. M. Schmaltz, T. C. Bozeman, R. Paul, M. J. Rishel, K. S. Tsosie and S. M. Hecht, J. Am. Chem. Soc., 2013, 135, 2883-2886.

13 Z. GEstephan, Z. Qian, D. Lee, J. C. Crocker and S. J. Park, Nano Lett., 2013, 13, 4449-4455.

14 X. J. Chen, B. L. Sanchez-Gaytan, Z. Qian and S. J. Park, Nanomed. Nanobiotechnol., 2012, 4, 273-290.

15 P. Stoliar, E. Bystrenova, S. D. Quiroga, P. Annibale, M. Facchini, M. Spijkman, S. Setayesh, D. de Leeuw and F. Biscarini, Biosens. Bioelectron., 2009, 24, 2935-2938.

16 M. C. Breadmore, K. A. Wolfe, I. G. Arcibal, W. K. D. Leung Dickson, B. C. Giordano, M. E. Power, J. P. Ferrance, S. H. Feldman, P. M. Norris and J. P. Landers, Anal. Chem., 2003, 75, 1880-1886.

17 K. A. Melzak, C. S. Sherwood, R. B. F. Turner and C. A. Haynes, J. Colloid Interface Sci., 1996, 181, 635.

18 Y. Mao, L. Y. Daniel, N. Whittaker and U. Saffiottil, Environ. Health Perspect., 1994, 102, 165.

19 S. M. Solberg and C. C. Landry, J. Phys. Chem. B, 2006, 110, 15261-15268.

20 H. Tian, A. F. R. Huhmer and J. P. Landers, Anal. Biochem., 2000, 283, 175-191.

21 M. Khanna, M. Yoder, L. Calamai and G. Stotzky, Sci. Soils, 1998, 3, 1-10.

22 M. Fujiwara, F. Yamamoto, K. Okamoto, K. Shiokawa and R. Nomura, Anal. Chem., 2005, 77, 8138-8145.

23 V. Mayen, T. Wutikhun, O. Ketchart and P. Kopermsub, Journal of the Microscopy Society of Thailand, 2012, 5, 10-13.

24 D. Avnir, T. Coradin, O. Lev and J. Livage, J. Mater. Chem., 2006, 16, 1013-1030.

25 A. S. Dorcheh and M. H. Abbasi, J. Mater. Process. Technol., 2008, 199, 10-26.

26 S. S. Kistler, Nature, 1931, 127-741.

27 L. W. Hrubesh, J. Non-Cryst. Solids, 1998, 225, 335-342.

28 M. A. B. Meador, E. F. Fabrizio, F. Ilhan, G. A. Dass, P. Zhang, J. C. Vassilaras and N. L. Johnston, Chem. Mater., 2005, 17, 1085-1098.

29 M. Reim, A. Beck, W. Korner, R. Petricevic, M. Glora, M. Weth, T. Schliermann, J. Fricke, C. Schmidt and F. J. Potter, Sol. Energy, 2002, 2, 21.

30 M. Reim, G. Reichenauer, W. Körner, J. Manara, M. ArduiniSchuster and S. Korder, J. Non-Cryst. Solids, 2004, 350, 358363.

31 S. A. Omer, S. B. Riffat and G. Qiu, Building Services Engineering Research and Technology, 2007, 28, 275.

32 A. C. Pierre and G. M. Pajonk, Chem. Rev., 2002, 102, 4243. 
33 J. Estella, J. C. Echeverria, M. L. Julian and J. Garrido, J. Porous Mater., 2008, 15, 705.

34 M. Alnaief and I. Smirnova, J. Non-Cryst. Solids, 2010, 356, 1644-1649.

35 P. Buisson, C. Hernandez, M. Pierre and A. C. Pierre, J. NonCryst. Solids, 2001, 285, 295-302.

36 I. Smirnova, J. Mamic and W. Arlt, Langmuir, 2003, 19, 85218525.

37 I. Smirnova, S. Suttiruengwong and W. Arlt, J. Non-Cryst. Solids, 2004, 350, 54-60.

38 Y. K. Li, M. J. Chou, T. Y. Wu, T. R. Jinn and Y. W. ChenYanga, Acta Biomater., 2008, 4, 725-732.

39 F. Sabri, J. D. Boughter Jr, D. Gerth, O. Skalli, T. N. Phung, G. R. M. Tamula and N. Leventis, PLoS One, 2012, 7(12), e50686, DOI: 10.1371/journal.pone.0050686.

40 J. Ge, M. Li, Q. Zhang, C. Z. Yang, P. H. Wooley, X. Chen and S. Yang, Silica Aerogel Improves the Biocompatibility in a Poly- $\varepsilon$-Caprolactone Composite Used as a Tissue Engineering Scaffold, Int. J. Polym. Sci., 2013, DOI: 10.1155/ 2013/402859.

41 Y. K. Li, D. K. Yang, Y. C. Chena, H. J. Suc, J. C. Wub and Y. W. Chen-Yanga, Acta Biomater., 2010, 6, 1462-1470.

42 J. Martin, B. Hosticka and P. Norris, J. Non-Cryst. Solids, 2001, 285, 222-229.
43 M. Mukhopadhyay and B. S. Rao, J. Chem. Technol. Biotechnol., 2008, 83, 1101-1109.

44 M. Tanigawa, M. Suzuto, K. Fukudome and K. Yamaoka, Macromolecules, 1996, 29, 7418-7425.

45 N. Sundaresan, H. C. Suresh, T. Thomas, T. J. Thomas and C. K. S. Pillai, Biomacromolecules, 2008, 9, 1860-1869.

46 Y. Ru, L. Guoqiang and L. Min, Microporous Mesoporous Mater., 2010, 129, 1.

47 A. Wu, Z. Li and E. Wang, Anal. Sci., 2004, 20, 1083-1086.

48 H. Zhao, J. Chem. Technol. Biotechnol., 2015, 90, 19-25.

49 P. Cai, Q. Huang, D. Jiang, X. Rong and W. Liang, Colloids Surf., B, 2006, 49, 49-54.

50 G. Stotzky, J. Environ. Qual., 2000, 29, 691-705.

51 F. Ke, Y. K. Luu, M. Hadjiargyrou and D. Liang, Characterizing DNA Condensation and Conformational Changes in Organic Solvents, PLoS One, 5(10), e13308, DOI: 10.1371/journal.pone.0013308.

52 D. L. Nelson and C. M. M. Lenhinger, Principles of Biochemistry, Wroth, NewYork, 2000.

53 A. Fidalgo and L. M. Ilharco, Microporous Mesoporous Mater., 2005, 84, 229-235.

54 P. Munnik, M. Wolters, A. Gabrielsson, S. D. Pollington, G. Headdock, J. H. Bitter de, P. E. Jongh and K. P. de Jong, J. Phys. Chem. C, 2011, 115, 14698-14706.

55 X. Li, J. Zhang and H. Gu, Langmuir, 2011, 27, 6099-6106. 